\title{
TEACHER CREATIVITY IN FORMING CHARACTER EDUCATION
}

\author{
Muhammad Hifdil Islam, Mohammad Hilmy Baihaqy Yussof \\ Universitas Islam Zainul Hasan Genggong, Indonesia \\ Universiti Islam Sultan Sharif Ali, Brunei Darussalam \\ muhammad.hifdil@gmail.com \\ baihaqy313@gmail.com
}

Received: 15-06-2019

Revised: 10-09-2019

Accepted: 07-11-2019

\begin{abstract}
The law No.20 of 2003 article 3 states that national education in Indonesia has a functions to develop capabilities and shape the character and civilization of a dignified nation in the context of the intellectual life of the land, aiming at improving the potential of learners to become human beings who believe in and have faith in God Almighty, moral noble, healthy, knowledgeable, capable, creative, independent, and be a democratic, responsible citizen. Character education can be seen from two great perspectives, namely how he can recognize, behave and manage himself, and recognize, behave, and lead others. More explicitly, character education is an essential platform for social control based on self-awareness. Based on the research that I have done there turns out to be a significant relationship between the successful application of character education in schools with the creativity of teachers. That is, the more creative a teacher is in implementing character education in schools, the higher the success of character education for students. Based on that conclusion, the authors suggest that every teacher has high creativity in the application of character education in schools. The trick is always to deepen the notion of creativity, the characteristics of creative teachers, and ways to develop creativity. Thus it is expected that the application of character education in schools runs effectively and efficiently.
\end{abstract}

Keywords: Forming, Character Education, Teacher Creativity,

\section{Abstrak}

Undang-undang Nomor 20 Tabun 2003 pasal 3 menyebutkan bahwa pendidikan nasional di Indonesia mempunyai fungsi untuk. mengembangkan kemampuan dan membentuk. karakter serta peradaban bangsa yang bermartabat dalam rangka mencerdaskan kehidupan bertanah, bertujuan untuk meningkatkan potensi peserta didik. menjadi manusia yang beriman dan beriman kepada Tuban Yang Maha Esa, berakblak mulia, sehat, berilmu, cakap, kreatif, mandiri, dan menjadi warga negara yang demokratis, bertanggung jawab. Pendidikan karakter dapat dilihat dari dua perspektif besar, yaitu bagaimana ia dapat mengenali, berperilaku dan mengatur dirinya sendiri, serta mengenali, berperilaku, dan memimpin orang lain. Lebih eksplisit lagi, pendidikan karakter adalah platform penting untuk kontrol sosial yang didasarkan pada kesadaran diri. Berdasarkan penelitian yang telah saya lakukan ternyata terdapat bubungan yang signifikan antara keberbasilan penerapan pendidikan karakter di sekolah dengan kreativitas guru. Artinya, semakin kreatif seorang guru dalam melaksanakan pendidikan karakter di sekolah maka semakin tinggi pula keberhasilan pendidikan karakter bagi siswa. Berdasarkan kesimpulan tersebut, penulis menyarankan agar setiap guru memiliki kreativitas yang tinggi dalam penerapan pendidikan karakter di sekolah. Triknya selalu dengan memperdalam pengertian tentang kreativitas, karakteristik guru yang kreatif, dan cara mengembangkan kreativitas. Dengan demikian diharapkan penerapan pendidikan karakter di sekolah berjalan efektif dan efisien.

Kata kunci: Pembentukan, Pendidikan Karakter, Kreativitas Guru 


\section{INTRODUCTION}

Education is the process of internalizing culture into a person and society to make people and society civilized. Education is not only a means of transferring knowledge but rather as a means of acculturation and distribution of values. Children must get an education that touches the basic dimensions of humanity. The human dimension includes at least three of the essential things: (1) affective which reflected in the quality of faith, loyalty, noble character, noble character, superior personality, and aesthetic competence, (2) cognitive as indicated in thinking capacity and powerful intellect to explore and develop and master science and technology, and (3) psychomotor reflected in the ability to develop technical skills, practical skills, and kinesthetic competence. ${ }^{1}$

Character education can be seen from two points of view, namely, how he can recognize, behave, and manage itself and recognize, behave and manage others. More explicitly, character education is an essential platform for social control based on selfawareness ${ }^{2}$. The experts mentioned as a measure or indicator of human intelligence, namely intelligence $($ Intelligence Quotient $=\mathrm{IQ})$, emotional intelligence $($ Emotional Quotient $=\mathrm{EQ})$, and spiritual intelligence (Spiritual Quotient $=\mathrm{SQ})^{3}$.

As an eastern nation that bases itself on the values of community and togetherness, the Indonesian people need to be strengthened in terms of self-worth and individuality so that in association social power of self-values that are internalized in individuals that form communal values and national values ${ }^{4}$. The benefits of the Indonesian people are, namely universal values and religious spirit and cultural values.Education in Indonesia and the future must be able to build and educate students of character. To measure the level of a person's character level, German education expert FW Foersterexpresses four essential characteristics, namely (1) every action is estimated based on the level of the hierarchy of values, (2) the courage to hold fast to the principles and not run away from risk, (3) the internalization of values and norms outside the self so that it is integral to his personality, and (4) determination and loyalty in upholding the ideals of goodness and respect for the choices made.

\footnotetext{
${ }^{1}$ Hamka Abdul Aziz, Pendidikan karakter berpusat pada hati: akblak mulia, pondasi membangun karakter bangsa (Al-Mawardi Prima, 2011), 175.

2 Adrian Albin-Clark, "Simulating Characters for Observation: Bridging Theory and Practice," [Thesis]. Manchester, UK: The Un iversity of Manchester; 2012., 14 Desember 2012, https://www.escholar.manchester.ac.uk/uk-ac-man-scw:183506.

${ }^{3}$ Noha El-Bassiouny, Ahmed Taher, dan Ehab Abou-Aish, "An empirical assessment of the relationship between character/ethics education and consumer behavior at the tweens segment: the case of Egypt," Young Consumers 12, no. 2 (14 Juni 2011): 159-70, https:/ / doi.org/10.1108/17473611111141614.

${ }^{4}$ Howard Kirschenbaum, 100 ways to enhance values and morality in schools and youth settings (Boston: Allyn and Bacon, 1995).
} 
Values are normative guidelines for every attitude and action. Persistence in holding the principle makes someone durable not to be easily swayed by any circumstance. Internalization of values and norms provides the ability to judge in decision making without the intervention of others. While persistence is the endurance to believe what is considered good and a strong commitment to the decision chosen ${ }^{5}$.

The education unit is a vehicle for character building and development carried out by using (1) integrated approaches in all subjects, (2) developing the culture of the education unit, (3) implementing co-curricular and extracurricular activities, and (4) capitalizing behaviour in life in the unit environment education. Character development through education units is carried out starting from early childhood education to higher education.

One of the keys to the success of the character development program in the education unit is the role model of educators. Exemplary is not just an example for students, but also as a sound reinforcement for students to behave and behave.

\section{DISCUSSION}

\section{Cultural Education and Nation Character}

Law of the Republic of Indonesia Number 20/2003 concerning the National Education System (National Education System) formulates the functions and objectives of national education that must be used in developing educational efforts in Indonesia. Article number three of the national education system Law states that governmental education functions to create and shape the character and civilization of a dignified nation in the context of educating the life of a dignified nation in the context of teaching the life of the nation, aiming at developing the potential of students to become human beings who believe in and fear God Almighty, have a morality noble, healthy, knowledgeable, capable, creative, independent, and be a democratic and responsible citizen ${ }^{6}$.

The purpose of national education is the formulation of the quality of Indonesian people that must be developed by each education unit. Therefore, the wording of the objectives of civic education becomes the basis in the development of national culture and

5 Siswanto, "The Islamic Moderation Values on the Islamic Education Curriculum in Indonesia: A Content Analysis," Jurnal Pendidikan Islam 8, no. 1 (2019): 121-52, https://doi.org/10.14421/jpi.2019.81.121-152; Ansori, "Internalisasi Nilai-Nilai Pendidikan Karakter Dilingkungan Madrasah Dan Sekolah," At-Tasyrib: Jurnal Pendidikan Islam 1, no. 1 (1 September 2015): 66-81, http://ejournal.stai-muarabulian.ac.id/index.php/AtTasyrih/article/view/15.

${ }^{6}$ E Mulyasa, Manajemen Pendidikan Karakter, 5 ed. (Jakarta: Bumi Aksara, 2016); Muzhoffar Akhwan, "Pendidikan Karakter: Konsep dan Implementasinya dalam Pembelajaran di Sekolah/Madrasah," EL TARBAWI 8, no. 1 (2014): 61-67; Thomas Lickona, Character matters: how to help our children develop good judgment, integrity, and other essential virtues (New York: Simon \& Schuster, 2004). 
character education.In gaining cultural education and national character, it is necessary to state the terms culture, national character, and education. The definitions expressed herein are put forward technically and used in developing this guideline. Anthropology, Citizenship Education teachers and other subjects whose terms are the subject of related subjects, still have complete freedom to discuss and argue on these terms academically.

Culture is defined as the whole system of thinking, values, morals, norm, and human beliefs generated by society. Systems of thought, values, morals, standards and ideas are the result of human interaction with each other and their natural environment. Systems of thinking, values, morals, norms, and beliefs are used in human life and produce social systems, economic systems, belief systems, knowledge systems, technology, art, and so on. Education is a planned effort in developing the potential of students, so they have a system of thinking, values, morals, and beliefs that are inherited by their communities and promote the inheritance in a direction that is appropriate for present and future life ${ }^{7}$.

Character is the character, character, character, or personality of a person that is formed from the internalization of various virtues that are believed to be used as a basis for perspective, thinking, acting and acting. Morality consists of several values, morals, and norms, such as: honest, brave to act, trustworthy, and respectful of others. One's interactions with others give rise to the character of society and the character of the nation. Therefore the development of national character can only be done through the development of one's personality. However, because humans live in specific social and cultural environments, a person's individual character development can only be done in the relevant social and cultural context.The social and cultural environment of the nation is Pancasila. So, cultural education and national character must be based on Pancasila values. In other words, educating the culture and nature of the nation is to develop Pancasila values in students through heart, brain, and physical education. The function of cultural education and national character are: Development. developing the potential of students to become well-behaved individuals; Repair. strengthen the role of civic education to be responsible for developing the possibility of more dignified learners, and Filter: to filter the culture of their nation and the cultures of other countries that are not following the cultural values and character of a dignified society.

7 Thomas Lickona, Educating for Character: How Our Schools Can Teach Respect and Responsibility (New York: Bantam Books, 2009); J. Stewart Black dan Allen J. Morrison, “The Character of Global Leaders," dalam Advances in Global Leadership, vol. 8, 0 vol., Advances in Global Leadership 8 (Emerald Group Publishing Limited, 2014), 183-204, https://doi.org/10.1108/S1535-120320140000008016. 
Furthermore, The aims of the nation's cultural and character education are: Developing the heart/conscience/affective potential of students as human beings and citizens who have cultural values and national character; Developing the habits and behaviour of students who are praiseworthy and in line with the universal values and national cultural traditions that are religious; 1) Instil the spirit of leadership and responsibility of students as the next generation of the nation; 2) Develop students' abilities to become independent, creative, national-minded, and human beings 3) It is developing a school life environment as a learning environment that is safe, honest, full of creativity and friendship, as well as with a high sense of nationality and full strength (dignity) $)^{8}$.

In conclusion, cultural education and national character are interpreted as education that develops the cultural values and national character of the learners.So, they have values and attitudes as their characters, applying the values these values in his life, as members of the community, and citizens who are religious, nationalist, productive, and creative.

\section{Values in Cultural Education and Nation Character}

Values developed in cultural education and national character are identified from the following sources:

Religion: Indonesian society is a religious society. Therefore, the lives of individuals, communities, and nations are always based on spiritual teachings and beliefs.

Pancasila: the unitary state of the Republic of Indonesia is affirmed on the principles of national and state life called Pancasila. Pancasila is contained in the Preamble to the 1945 Constitution and further elaborated in the articles contained in the 1945 Constitution. The values listed in Pancasila become the values that govern political, legal, economic, social, cultural, and artistic life.

Culture: as a truth that no human lives in a society that is not based on cultural values recognized by the community. Cultural values are used as a basis in giving meaning to a concept and definition in communication between members of the community.

National Education Objectives is a quality formula that must be possessed by every Indonesian citizen, developed by various education units at multiple levels and pathways. National education goals contain different human values that must be owned by Indonesian citizens. Therefore the aim of civic education is the most operational source in

\footnotetext{
${ }^{8}$ Mohamad Iwan Fitriani, "Systemic and Systematic Steps of Leadership on Transforming Symbolic into Substantive Characteristic of Madrasah," Jurnal Pendidikan Islam 3, no. 1 (22 Juni 2017): 1-16, https://doi.org/10.15575/jpi.v3i1.1203; Asror Baisuki dan Ta'rif Ta'rif, "Penanaman Karakter Moderat Di Ma’had Aly Situbondo," EDUKASI: Jurnal Penelitian Pendidikan Agama Dan Keagamaan 15, no. 3 (31 Desember 2017), https://doi.org/10.32729/edukasi.v15i3.456.
} 
the development of national culture and character education (Moh.Saleh in Wijono, Suko, 2011: 47) $3^{9}$.

Theoretically, it can be argued that character education that emphasizes the ethicalspiritual dimension in the process of personal formation is the German pedagogue, FW Foerster. Character education is as a reaction to ignorance of Rousseauian and natural pedagogies. Moreover, puerocentric pedagogy through celebrations of children's spontaneity (Edouard Claparede, Ovide Decroly, Maria Montessori), which coloured Europe and the United States in the early nineteenth century was increasingly deemed insufficient for an individual's intellectual and cultural formation.Anti-positivist and anti-naturalist polemics in early 19th century Europe were a movement of liberation from natural determinism towards a spiritual dimension, moving from a personal formation with a psychosocial approach to more basic humanistic ideals. Character education is an attempt to revive the ideal spiritual pedagogy which was lostwave of positivism a la Comte.

The purpose of education is to form the character that is manifested in the essential unity of the subject with the behaviour and attitude of life they have. For Foerster, a character is something that qualifies a person. The character becomes an identity that transcends everchanging contingent experiences. From the maturity of this character, the quality of a person is measured.

According to Foerster, there are four necessary in character education. First, interior order in which every action is measured based on a hierarchy of values. Values become normative guidelines for every effort.Second, a coherence that gives courage, makes a person firm on principles, is not easily swayed by new situations or afraid of risk. Consistency is the foundation upon which to build mutual trust. Lack of coherence undermines one's credibility.Third, autonomy. Someone internalizes the rules from the outside to become values for the person. And, it can be seen through the evaluation of personal decisions without being influenced or pressured by others.Fourth, determination and loyalty. Persistence is a person's endurance to covet what is considered excellent. Out of obedience is the basis for respect for the chosen commitment ${ }^{10}$.

9 Zainal Arifin, "Pendidikan multikultural-religius untuk mewujudkan karakter peserta didik yang humanis-religius," Jurnal Pendidikan Islam 1, no. 1 (2012): 89-103.

10 Zubaedi, Desain Pendidikan karakter, Konsepsi dan Aplikasinya dalam Pendidikan (Jakarta: Kencana Prenada, 2011); Hilda Ainissyifa, "Pendidikan Karakter dalam Perspektif Pendidikan Islam," Jurnal Pendidikan UNIGA 8, no. 1 (20 Februari 2017): 1-26, https://journal.uniga.ac.id/index.php/JP/article/view/68; Chelsea Graff, "The Effectiveness of Character Education Programs in Middle and High Schools," Counselor Education Master's Theses, 1 April 2012, https://digitalcommons.brockport.edu/edc_theses/127. 
The maturity of these four characters continued Foerster, allows humans to pass through the stage of individuality to personality. "Modern people often confuse individuality and personality, between natural and spiritual me, between exterior and interior independence." This character determines the form of a person in all his actions.On the sidelines of the orientation of increasing institutional capacity and organizing community education programs in Surabaya, the presenters of various television programs rated that character education should not be specific. The character must not be unique but included in the curriculum of all subjects-for example,knowledge of culture, religion, economics, mathematics, entrepreneurship, and so on. For example, economics or entrepreneurship must be given "inserts" material that teaches about honesty, trust, courage, etc. If it is on formal education that is specific such as Pancasila or character,the character education will be challenging to enter because it only becomes knowledge or memorization ${ }^{11}$.

Character education in schools is vital, although the basis of character education is in the family. If a child gets a good character education from his family, the child will be of good character next. But many parents are more concerned with aspects of brain intelligence than character education. Besides, Daniel Goleman also said that many parents fail to educate their children's character either because of busyness or because they are more concerned with the cognitive aspects of children. However, this can all be corrected by providing character education in schools. ${ }^{12}$

The problem iseducation policy in Indonesia is also more concerned with aspects of brain intelligence. Only recently has the importance of character education been the subject of discussion. Some say that the education curriculum in Indonesia is made only suitable to be given to 10-20 percent of the best brains. That is, the majority of school children (80-90 percent) cannot follow lessons based on the existing curriculum at school. As a result of an early age, most children will feel "stupid" because of difficulty adjusting to the current curriculum. They are coupled with the existing ranking system that has sentenced children who did not enter the "top 10" to be less intelligent. Such a system certainly hurts efforts to build character, where children are already "killed" by their self-confidence ${ }^{13}$.

11 Abdul Majid dan Dian Andayani, Pendidikan agama Islam berbasis kompetensi: konsep dan implementasi kurikulum 2004, Cet. 1 (Bandung: Remaja Rosdakarya, 2004); Abd Majid, Pendidikan berbasis ketubanan membangun manusia berkarakter (Bogor: Ghalia Indonesia, 2014).

12 Dian Popi Oktari dan Warlim Warlim, "Internalization of Values Character Education in Learning English" (Eleventh Conference on Applied Linguistics (CONAPLIN 2018), Atlantis Press, 2019), 416-21, https://doi.org/10.2991/conaplin-18.2019.294.

13 Hermino Agustinus, Manajemen Kurikulum Berbasis Karakter: Konsep, Pendekatan dan Aplikasi (Bandung: Alfabeta, 2014); Bahrissalim Bahrissalim dan Fauzan Fauzan, "Evaluasi Kurikulum Pelatihan Dalam 
A prolonged disability will form a person who is not confident. It will even cause prolonged stress, as well. At the age of adolescence, usually, this situation will push a teenagerto behave negatively. So it is not surprising if we see the behaviour of our adolescents who like to fight, engage in crime, drop out of school, and decrease the quality of junior and senior high school graduates.So, character building for character education plus is an urgent thing to do. If we care to improve the quality of SD / MI, SMP / MTs, SMA / SMK / MA graduates, then without character education is a futile effort. I want to quote the words of wisdom from the great thinkers of the world. Mahatma Gandhi warned of one fatal sin, namely "Education without character" (education without character). Dr. Martin Luther King once said that "Intelligence plus character is the goal of true education." Also, Theodore Roosevelt, who said, "To educate a person in mind and not in morals is to educate a menace to society" (Educating someone in the intelligence aspect of the brain and not the moral issue is a dangerous threat to society).

Building Indonesian people is to build a society that has character and has positive thinking that was created from an early age. Character education will be faster when supported by the government and included in the national education curriculum. According to Conny, character education must be built since the fetus is still in the womb. It is then continued by the education system to grow the national character so that it will form an Indonesian human person who is committed to not doing actions in the interest of only supporting the welfare of a handful of elites. ${ }^{14}$

Character education from an early age, he added, so that characters become a mindset that starts from oneself. So, humans can suppress their animalistic nature so that they do not appear to the surface.Conny said the inclusion of character education in the school curriculum would accelerate the socialization of character education. Including conducting socialization to parents because character education is not only done in schools but also the environment.

Character education, he continued, will process human traits, bring sincerity, and highlight virtue. Character education is critical because character formation is most influenced by the environment, in addition to intrinsic genetic factors.Education Character must occur

\footnotetext{
Meningkatkan Kompetensi Pedagogik Guru Pai Di Balai Diklat Keagamaan Jakarta," Edukasia: Jurnal Penelitian Pendidikan Islam 13, no. 1 (25 Juli 2018): 25-52, https://doi.org/10.21043/edukasia.v13i1.2779.

${ }^{14}$ Hasan Baharun dan Rohmatul Ummah, “Strengthening Students' Character in Akhlaq Subject Through Problem Based Learning Model," Tadris: Jurnal Keguruan Dan Ilmu Tarbiyah 3, no. 1 (29 Juni 2018): 21-30, https://doi.org/10.24042/tadris.v3i1.2205; Zainal Arifin, "The Authority of Spiritual Leadership at Pesantren Temboro Based on Jamaah Tabligh Ideology," Jurnal Pendidikan Islam 6, no. 2 (27 Desember 2017): 265-92, https://doi.org/10.14421/jpi.2017.62.265-292.
} 
intentionally and become the Grand design of the Ministry of Education and Culture. Although psychologically the young people who are educated in their character must not feel that the government is teaching their character. "Good character will create a harmonious social environment, even though we have to face different human beings," explained Conny.

While Franz Magnis Suseno also the speaker, stated that the Indonesian nation had always been a nation of character. Even in the world of foreign education, Indonesian students still mediate the conflicts that occur between students.But now, he said, the character of the nation was threatened because of hedonistic consumerism that descended on the nation's leaders. As a result, many people forget their people.Character, according to Franz, is the attitude of someone who has confidence and acts on his beliefs. He was concerned about the erosion of the nation's character as contained in the philosophy of Pancasila by many factors. For example, openness and tolerance are threatened by fanaticism and shortsightedness. Including a determination to always carry oneself civilized that is threatened by barbarity and violence.

\section{The Need for Environmental Support in Building Character Education}

Character education has become a serious discussion, ranging from state forums to remote villages. In seeing this phenomenon, the government is trying to continue to be committed to making various efforts to facilitate it while still expecting support from various parties.Many experts are now working on the right character education model to shape an excellent national person. Indeed, the effort in building character education cannot be separated from the support of the surrounding environment, including the world of school, parents, and the community. The formation of an ethical generation not only from reading books, but also practice. Because that's where will form a character, it is what needs to be set as an example with support from various parties. Furthermore, Boediono added, educational success cannot be said to be optimal if it is not balanced with good character. Because to be a good leader, there are two crucial things that many young people have. These two things are knowledge and skills that are balanced with good character.Megawangi stated that based on Socrates' philosophy, the most fundamental purpose of education is to transform a person to become good and smart individuals. An educated man should be a wise person, who can make use of his knowledge for good deeds, and finally lead a discreet life in all aspects of family, neighborhood, society, and country settings. Therefore, a successful education system 
is the one that could equip its members with good characters highly needed in establishing a respected nation-state ${ }^{15}$.

Character education is one of the important aspects that must be possessed by the younger generation to become a leader. What is meant here is how to maximize academic achievement, which is not just theory but also practice. The environment is very supportive of achieving the goals of character education. If the children have implemented character education at school, but the atmosphere is less favourable, then it is possible for children will return to change as before. That is, the character of a good child will be eroded by environmental influences. So strong is the influence of the environment that it can be explained that in achieving the success of children's character education, the environment has a significant role.

\section{Impact of Character Education}

What impact does character education have on academic success? Several studies have sprung up to answer this question. A summary of some important discoveries regarding things This is published by a bulletin, Character Educator, which is issued by the Character Education Partnership.In explained that the results of the study of Dr.Marvin Berkowitz from the University of Missouri - St. Louis, showed an increase in the motivation of school students to achieve academic achievement in schools that implement character education. Classes that are comprehensively involved in character education show a drastic reduction in negative student behaviour which can hinder academic success. ${ }^{16}$

Character education is character education plus, which includes aspects of knowledge (cognitive), feelings (feeling), and action (action). According to Thomas Lickona, without these three aspects, character education will not be effective, and its implementation must be carried out systematically and continuously. With character education, a child will become emotionally intelligent. Emotional intelligence is the most critical provision in preparing children for the future because, with it, someone will be able to succeed in facing all kinds of challenges, including challenges to succeed academically ${ }^{17}$.

Joseph Zins compilesmany research results about the positive influence of children's emotional intelligence on success in school. It is said that there are a series of risk factors that cause child failure at school. The risk factors mentioned are not in the intelligence of the

15 Ratna Megawangi, "Pengembangan program pendidikan karakter di sekolah: pengalaman sekolah karakter," 2010.

${ }^{16}$ Aynur Pala. The Need of Character Education. International Journal ofSocial Science and Humanity Studies. Vol. 3 No. 2. 2011 ISSN. 1309-8063

${ }^{17}$ Lickona, Educating for Character. 
brain, but in character, namely self-confidence, the ability to work together, the ability to get along, the ability to concentrate, a sense of empathy, and the ability to communicate. It is following Daniel Goleman's opinion about one's success in society. Apparently, 80 percent is influenced by emotional intelligence, and only 20 percent is determined by brain intelligence (IQ) ${ }^{18}$

Children who have problems in emotional intelligence will have difficulty learning, socializing, and can not control their emotions. Children who have issues are already albeIt hasn't been seen since preschool age, and if left untreated, it will carry over into adulthood. Conversely, adolescents who have a character or have high emotional intelligence will avoid common problems faced by adolescents such as delinquency, brawl, drugs, alcohol, free sex, and so on.According to Hamka Abdul Aziz in the book Character Education Centered on the beart. ${ }^{19}$ centres play a central role in all human activities and behaviour. Even with Allah, human existence is primarily determined by the quality of his heart. Not the quality of the material world, which often leaves only a good impression, not the good itself. In a Bimbo group song-poem, it says "The heart is a mirror, a place of reward and sin to fight." It shows how the heart occupies a very strategic position in humans.

Almost most people act, work, or do other activities that do not make the heart as a driving force. They prefer "other elements" as the activator. Though the human heart tends to the truth. He is brilliant, can understand which is right andwhich one is wrong. By havinga character education, the hearts of our children will always be honed. If the heart is continually honed, the dirt will disappear. If the impurities of the heart dissolve, then their behaviour will follow rightaction, which is polite. In the eyes of religion, it is said that they already have noble character or akblakul karimah ${ }^{20}$.

If children have lofty morals, then not only parents who are happy, the teachers, friends, the community, and anyone will feel satisfied. Children who hang out with children of noble character will feel how beautiful friendship is. They will love each other, respect each other, and advise one another.If their behaviour is like that, then the community will be calm.

18 Joseph E. Zins dkk., "Social and emotional learning for successful school performance," dalam The science of emotional intelligence: Knowns and unknowns, Series in affective science (New York, NY, US: Oxford University Press, 2007), 376-95.

19 Aziz, Pendidikan karakter berpusat pada hati, 204.

20 Aan Hasanah, Neng Gustini, dan Dede Rohaniawati, "Cultivating Character Education Based on Sundanese Culture Local Wisdom," Jurnal Pendidikan Islam 2, no. 2 (21 Juni 2016): 231-53, https://doi.org/10.15575/jpi.v2i2.788; Andika Aprilianto dan Wahyuni Mariana, "Permainan Edukasi (Game) Sebagai Strategi Pendidikan Karakter," Naz̧hruna: Jurnal Pendidikan Islam 1, no. 1 (5 September 2018): 139-58, https://doi.org/10.31538/nzh.v1i1.47. 
The community will not feel disturbed. People will feel that they live in peace and prosperity. A good relationship between partners will encourage the creation of a conducive atmosphere. A conducive atmosphere will arouse mutual love, love, and respect. It gives a very big impact of character education on children's lives in the family, experience in school life, even in the life of the nation, and state. We certainly miss life very much like that. ${ }^{21}$

\section{Teacher's Creativity}

If character education is seen from the learning dimension, then inevitably want the teacher's role to be significant. It is because the teacher acts as an agent of change in learning. Indeed, in the modern learning approach, the teacher is not the only source that can be used as a reference by students. However, in character education, the authors see that the teacher's role is very urgent. Therefore I dare say that the success of character education is inseparable from the creativity of the teacher. With such an emphasis, not all teachers can contribute maximally to the achievement of character education goals. Only the creative teacher will be able to encourage the achievement of these character education goals.

Creativity is a complicated field of study, which gives rise differences of views. The difference lies in the definition of creativity, the criteria of creative behaviour, creative processes, the relationship of creativity and intelligence, the characteristics of creative people, the correlates of creativity, and efforts to develop creativity. In recent years, there is a new topic that invites many responses, namely the relationship of creativity and brain hemisphere ${ }^{22}$.

Creativity is defined differently. So diverse are definitions that the notion of creativity depends on how people interpret it. Not a single description is considered a different representative understanding of creativity. It is due to two reasons. First, as a "hypothetical construct," creativity is a complex and multidimensional psychological domain, which invites various interpretations. Second, the definitions of creativity put different stresses, depending on the theoretical basis on which the definition makers are used.Based on the emphasis,

${ }^{21}$ Muhammad Hifdil Islam, "Model Pendekatan Halaqotul Mu`Allimin Al-Islamiyah Dalam Membentuk Kepribadian Yang Rahmatan Lil Alamin Sebagai Identitas Kebangsaan Di Pondok Pesantren Al-Mashduqiah," Proceedings of Annual Conference for Muslim Scholars 3, no. 1 (26 November 2019): 491-503, http://proceedings.kopertais4.or.id/index.php/ancoms/article/view/263; Muhammad Hifdil Islam, "Tolerance in Persepective of Qur'an and Bibel (Comparative Analysis of Religious Tolerance in Diverses Community)," $\begin{array}{lllllll}\text { Humanistika } & 3, & \text { no. } & 2 & \text { Juni } & \text { 2017): }\end{array}$ https://www.ejournal.inzah.ac.id/index.php/humanistika/article/view/160.

22 Yeni Rachmawati, Strategi Pengembangan Kreativitas Pada Anak (Prenada Media, 2012). 
definitions of creativity can be divided into dimensions of person, process, product, and press. Rhodes in Supriadi, Dedi calls the four aspects of creativity as the Four P's of Creativity ${ }^{23}$.

Based on factor analysis, Guilford found five traits that characterize the ability to think creatively.Those are fluency (fluency), flexibility (flexibility), authenticity (originality), decomposition (elaboration), andredefinition. Smoothness is the ability to generate many ideas. Flexibility is the ability tosuggests various solutions or approaches to problems. Originality is the ability to come up with ideas in an original, not cliché way. Elaboration is the ability to describe something in detail. Redefinition is the ability to review an issue based on a perspective that is different from what many people already know. ${ }^{24}$

There are still many definitions of creativity. However, according to Dedi Supriadi, in essence, there are similarities between the definitions, viz creativity is a person's ability to give birth to something new, both in the form of ideas and real work, which is relatively different from what was there before. There is a close relationship between the definition and the theory of creativity. How creativity is defined depends on how creativity is theorized. As the definition of creativity,theories of creativity are very diverse. However, no theory can comprehensively explain the phenomenon of complex and multidimensional creativity. Therefore, there is an attempt to classify methods of creativity. The psychoanalytic theory assumes that the unconscious process underpins creativity. Creativity is a manifestation of psychopathology. Association theory views creativity as a result of the process of association and the combination of elements that already exist, to produce something new. Gestalt theory views creativity as a manifestation of the process of an individual's view of the environment in a manner holistic ${ }^{25}$. Interpersonal theory interprets creativity in the context of the social environment. The creator is as an innovator, and the others are as the party who recognizes the results of creativity. Then, the theory emphasizes the importance of the values and meanings of creative work. Value implies recognition socially. The approach of trait gives a special place for the effort to identify the main characteristics or characteristics of creativity.The definition is based on the following assumptions: (a) creative products or observable responses are manifestations of the peak of creativity, (b) creativity is something that can be recognized by outside observers, and they can agree that something is an original

${ }^{23}$ Dedy Supriyadi, Filsafat Islam, 3 ed., 3 (Bandung: Pustaka Setia, 2013).

24 J. P. Guilford, "Creative abilities in the arts," Psychological Review 64, no. 2 (1957): 110-18, https://doi.org/10.1037/h0048280.

${ }^{25}$ Howard Gardner, "Memory and the Brain," New York Times, 24 Februari 2003, bag. Editorials/Letters, http://search.proquest.com/docview/92578371/citation/3A9051008EB845DDPQ/20; Howard Gardner, Multiple intelligences: the theory in practice, 30. dr (New York, NY: Basic Books, 2002). 
product; (c) creativity varies in degree, and observers can come to an agreement that a product is more creative than the others. Consensual definitions are often used in the study of creativity in the scientific and artistic fields, both concerning products, people, processes, and the environment in which creative people develop their creativity.Conceptual definitions depart from certain concepts of creativity, which are translated into criteria about what is called creative. Although it still emphasizes the product side, this definition does not rely solely on the consensus of the observer in assessing creativity but is based on specific criteria.In the practice of evaluating creativity (i.e., the product and the person), the creativity criteria included in the conceptual definition will ultimately depend on the judgment of the assessor who is usually more than one person: to what extent do they agree that something or someone is creative? Therefore, in both definitions, subjective considerations are extensive ${ }^{26}$.

Then, Among the various definitions of creativity, the explanations are initiated by Stein, representing the conceptual definition and consensual definition of creativity. ${ }^{27} \mathrm{He}$ strongly emphasizes the aspect of creative products that have been real, as shown in original work. Word novel(new) means that a product that is considered creative is original. Although it does not mean completely new, the outcome reflects the results of new combinations or the effects of reintegrating things that already exist, thus giving birth to something new. The weight of product creativity will appear to what extent it is different from what has been there before. In any field, human creativity does not occur ex-nihilo (coming from a vacuum) but is preceded by previous discoveries. It is especially evident in the field of science and technology. Even in development, something is not found ex-nihilo, because natural laws as the creator's creation have already existed. God created humans found.The statement "the creative work is tenable or useful or satisfying" implies that an original product must be valid, useful, and satisfying to the extent that it is valued by others. These three terms emphasize that the results of the creative process must be communicated to others so that the product experiences "consensual validation." No matter what a productcalled original by the manufacturer, as long as it has not been tested and consensually validated, which means it must be communicated, then the product has not yet been recognized for its creativity. Therefore, the recognition of others, especially experts, is essential.

26 Howard Gardner dan Thomas Hatch, "Educational implications of the theory of multiple intelligences," Educational researcher 18, no. 8 (1989): 4-10, http://edr.sagepub.com/content/18/8/4.short.

27 Morris I. Stein, "Creativity and Culture," The Journal of Psychology 36, no. 2 (1 Oktober 1953): 311-22, https://doi.org/10.1080/00223980.1953.9712897. 
Using conceptual and consensual definitions of creativity, a study of senior scientists for example, can use the following criteria: (a) their contribution to science, (b) membership in professional organizations, (c) awards that have been received, and (d) positions of expertise that have been or are currently held. In the field of science, the recognition of scientific work creativity is given by the scientific community in a field that is appropriate to the discipline of science. Recognition from others who are experts enables creative individuals to validate their works $^{28}$.

Next is the sentence,"The creative work is accepted at some point intime. "This sentence emphasizes the time dimension of people's acknowledgment of creative work. Work may be recognized as an extraordinary creative work at a time, but not so in the next period. In painting, for example, Vincent van Gogh's work was considered not extraordinary painting when he was still alive. However, a century later, the workshis work was sold for tens of millions of dollars because it was valued by the communityartists, critics, and art collectors, as special creative works. Likewise, in the scientific field, the theory which states that atoms are the smallest objects that cannot be subdivided is considered to be the most creative theory of its time. However, after the arrival of Madam Curie's theory, which states that atoms consist of protons, neutrons, and electrons, the previous theory experienced a decline in the value of creativity. So, the value of the creativity of a product depends on the time factor.

The creativity of a product depends not only on the time factor but also the place. Work may be considered creative in one place, but not so in another place. A discovery in the field of science and technology may be classified as rare in a country. However, in other countries, it has been found. This statement emphasizes that creativity also depends on contextual social culture.

Placing creativity in the context of a community of people who appreciate work, place, and time does not mean the intrinsic quality of the creative work is ignored. It is precisely this recognition given by others because the work has certain intrinsic qualities, in addition to having social significance. The creativity of a work is not only determined by the science interests but also, it is devoted to humanity's interests. On this basis, the scientific community is morally bound by scientific ethics in carrying out scientific endeavors.

${ }_{28}$ Ismail Ismail, "GURU KREATIF; Suatu Tinjauan Teoritis," Jurnal Al-Qalam: Jurnal Kajian Islam \& Pendidikan 11, no. 2 (28 Desember 2019): 15-30, https://doi.org/10.47435/al-qalam.v11i2.425. 
According to Dedi Supriadi ${ }^{29}$ there are six assumptions about creativitybags based on theory and various studies on creativity. First, everyone has different levels of creative ability. No one has no creativity, and what is needed is how to develop that creativity. Creativity is an ability that is owned by everyone with different levels. Every person is born with creative potential, and this potential can be developed and nurtured.Second, creativity is expressed in the form of original products, both in the form of objects and ideas (creative ideas). Creative products are the "top criteria" for evaluating one's creativity or reliability. High or low quality of one's creative work can be judged based on the originality or novelty of the work and its contribution constructively to the development of culture and civilization. This criterion is also used by the Nobel Prize Committee (Swedish Academy of Sciences) in determiningthis very prestigious prize for the fields of Chemistry, Physics, Medicine, Economics, Literature, and Peace.Third, the actualization of creativity is the result of a process of interaction betweenpsychological factors (internal) with the environment (external). In each person, the role of each element is different.Fourth, in a person and his environment,some factors can support or even hinder the development of creativity. These factors can be identified as similarities and differences in groups of individuals or between individuals with one another.Fifth, someone's creativity does not take place in a vacuum, but it is preceded by the results of the creativity of those who worked before. So, creativity is a person's ability to create new combinations of things that already exist so that it gives birth to something new. Sixth, creative work is not born just by chance, but through a series of innovative processes that require strong skills, skills, and motivation. Three factors determine a person's creative achievement, namely motivation or high commitment, expertise in the occupied field, and creative skills.

\section{The Relevance of Character Education and Teacher Creativity}

One aspect of creativity is the personality of peoplecreative This aspect is critical to understand as fundamental in giving appropriate treatment to someone to develop their creativity. Efforts to create a climate conducive to the development of creativity are only possible if the nature of creative abilities and the surrounding environment are understood in advance.

Guilford argues that in the strict sense of creativity refers to the skills that are characteristic of creative people, namely the originality of flexibility, fluency, and elaboration. Creative skills determine whether individuals can display their creative behaviour to some

\footnotetext{
${ }^{29}$ Dedi Supriadi, Kreativitas, kebudayaan, dan perkembangan Iptek (Alfabeta, 1996).
} 
extent, whether people who have skills capital creative will produce creative works, depending on the characteristics of motivation, attitude, and temperament. Therefore, two important issues need serious attention in the study of creativity, namely: how the potential for creativity can be identified, and how creative personality can be developed. ${ }^{30}$

Creative characteristics bags can be distinguished into cognitive and noncognitive traits. Cognitive characteristics include four characteristics of creative thinking, namely originality, flexibility, fluency, and elaboration. While noncognitive aspects, including motivation, attitudes, and creative personality. Noncognitive traits are as important as cognitive traits because they are not supported by personalityaccordingly, one's creativity cannot develop naturally. For example, according to the test of creative thinking, a person can think original, flexible, and fluently. But he is lazy and gives up easily, then that ability will not develop.

Based on literature review, Supriadi identifies 24 creative personality traits found in various studies, namely: (1) open to new experiences; (2) flexible in thinking and responding, (3) free in expressing opinions and feelings, (4) appreciating fantasy, (5) attracted to creative activities, (6) having own views and not easily influenced by others, (7) have a great curiosity, (8) tolerant of differences of opinion and uncertain situations, (9) dare to take calculated risks, (10) confident and independent, (11) have responsibility and commitment to the task, (12) persevering and not easily bored, (13) not running out of mind in solving problems, (14) rich in the initiative, (15) sensitive to environmental situations ${ }^{31}$.

According to the writer's assumption, the creativity of the teacher is crucial for the success, or failurecharacter education carried out in educational institutions, both TK / RA, SD / MI, SMP / MTs /, and SMA / SMK / MA. That is, it is in the hands of the creative teacher that character education will be useful and productive. The reason is that creative teachers always have effective ways to achieve character education goals. Even in other dimensions, creative teachers always have more extensive opportunities and opportunities to succeed than non-creative teachers. Thus it can be assumed that teacher creativity will encourage the achievement of character education goals compared to teachers who do not have creativity.

${ }^{30}$ Larry P. Nucci, Tobias Krettenauer, dan Darcia Narváez, ed., Handbook of moral and character education, Second edition, Educational psychology handbook (New York: Routledge, 2014); Robert J Sternberg, Handbook of Creativity, 1999.

31 Supriadi, Kreativitas, kebudayaan, dan perkembangan Iptek. 
As alluded to at the beginning of the article on the definition of creativity, five characteristics characterize the ability (teacher) of creative thinking, namely fluency, flexibility, authenticity, decomposition, and re-formulation.Teachers who can generate many ideas will try to find ideas so that the character education that is applied to their students is successful. They never run out of ideas. They are always looking for new ideas when the old plans are considered ineffective. The ability to generate these ideas will encourage students to make character education a behaviour, not just mere knowledge.Teachers who can express various solutions or approaches to problems will be able to encourage the achievement of character education for their students. Character education applied to students will be interesting because the teacher can express various solutions or approaches to problems. That is, every problem that comes to the surface caused by the application of character education in schools will be overcome by creative teachers or teachers who have creativity. Teachers who can come up with ideas in fundamental, original, or cliched ways will be able to make character education effective in school. Teachers will always find bright new ideas, so that character education becomes an integral part of the culture as a whole. Thus, teachers who have original ideas will be able to package character education well so that the desired goals are achieved. Teachers who can describe in detail will be able to carry out character education effectively. Why? Because the teacher will be able to analyze each problem in detail and then be able to overcome issues related to the implementation of character education.

Furhermore, Teachers who can review a problem based on a perspective that is different from what is already known by many people will be able to carry out character education with effects. Teachers with this ability have broad thinking about a problem, mainly only the issue of character education.Based on the five characteristics of creative thinking abilities above, the creative teacher is assumed to be able to carry out character education well if it is associated with a literature survey conducted by Supriadi (1985) about 24 creative personality traits found in various studies. If the 24 creative personality traits are attached to the teacher, the teacher's creativity is increasingly widespread and has diverse dimensions.

\section{CONCLUSION}

Therefore it can be stressed here that there is a significant relationship between character education and teacher creativity. That is, the more creative a teacher is in carrying out character education in schools, the more successful the character education goals will be. Several steps that can be taken by teachers who have creativity in carrying out character education in schools, namely:First, the teacher should understand what and how character 
education is. With this understanding, teachers will be able to apply character education correctly and effectively in their respective institutions.Second, the teacher should be able to choose which strategies will be used to implement character education. What is meant here is whether character education will stand-alone parallel to the subjects in the curriculum or character education is integrated into relevant topics. Whatever the choice, both have strengths and weaknesses. Even so, it is better than not carrying out character education. Third, the teacher should utilize his creativity in carrying out character education, both regarding approaches, techniques, and how to apply character education. The important thing is how character education goals are achieved by what we want.Fourth,teachers who have creativity will never know the word "unsuccessful" in implementing character education in schools. Therefore they must be able to carry out character education in schools by the level of ability, talent, and interests of students. Character education in TK/RA is undoubtedly different from in SD/MI. So it is with SMP/MTs and SMA/SMK/MA. By knowing the psychological background and potential of students at each level of education, the teacher who has creativity will be able to package character education into something exciting and is expected to become an integral part of student personality.

\section{REFERENCES}

Agustinus, Hermino. Manajemen Kurikulum Berbasis Karakter: Konsep, Pendekatan dan Aplikasi. Bandung: Alfabeta, 2014.

Ainissyifa, Hilda. "Pendidikan Karakter dalam Perspektif Pendidikan Islam.” Jurnal Pendidikan UNIGA 8, no. 1 (20 Februari 2017): 1-26. https://journal.uniga.ac.id/index.php/JP/article/view/68.

Akhwan, Muzhoffar. "Pendidikan Karakter: Konsep dan Implementasinya dalam Pembelajaran di Sekolah/Madrasah.” EL TARBAWI 8, no. 1 (2014): 61-67.

Albin-Clark, Adrian. "Simulating Characters for Observation: Bridging Theory and Practice." [Thesis]. Manchester, UK: The University of Manchester; 2012., 14 Desember 2012. https://www.escholar.manchester.ac.uk/uk-ac-man-scw:183506.

Ansori. "Internalisasi Nilai-Nilai Pendidikan Karakter Dilingkungan Madrasah Dan Sekolah." At-Tasyrib: Jurnal Pendidikan Islam 1, no. 1 (1 September 2015): 66-81. http://ejournal.stai-muarabulian.ac.id/index.php/At-Tasyrih/article/view/15.

Aprilianto, Andika, dan Wahyuni Mariana. "Permainan Edukasi (Game) Sebagai Strategi Pendidikan Karakter." Nazhbruna: Jurnal Pendidikan Islam 1, no. 1 (5 September 2018): 139-58. https://doi.org/10.31538/nzh.v1i1.47. 
Arifin, Zainal. "Pendidikan multikultural-religius untuk mewujudkan karakter peserta didik yang humanis-religius." Jurnal Pendidikan Islam 1, no. 1 (2012): 89-103.

. "The Authority of Spiritual Leadership at Pesantren Temboro Based on Jamaah Tabligh Ideology." Jurnal Pendidikan Islam 6, no. 2 (27 Desember 2017): 265-92. https://doi.org/10.14421/jpi.2017.62.265-292.

Aziz, Hamka Abdul. Pendidikan karakter berpusat pada hati: akblak mulia, pondasi membangun karakter bangsa. Al-Mawardi Prima, 2011.

Baharun, Hasan, dan Rohmatul Ummah. "Strengthening Students' Character in Akhlaq Subject Through Problem Based Learning Model." Tadris: Jurnal Keguruan Dan Ilmu Tarbiyah 3, no. 1 (29 Juni 2018): 21-30. https://doi.org/10.24042/tadris.v3i1.2205.

Bahrissalim, Bahrissalim, dan Fauzan Fauzan. "Evaluasi Kurikulum Pelatihan Dalam Meningkatkan Kompetensi Pedagogik Guru Pai Di Balai Diklat Keagamaan Jakarta.” Edukasia: Jurnal Penelitian Pendidikan Islam 13, no. 1 (25 Juli 2018): 25-52. https://doi.org/10.21043/edukasia.v13i1.2779.

Baisuki, Asror, dan Ta'rif Ta'rif. "Penanaman Karakter Moderat Di Ma'had Aly Situbondo." EDUKASI: Jurnal Penelitian Pendidikan Agama Dan Keagamaan 15, no. 3 (31 Desember 2017). https://doi.org/10.32729/edukasi.v15i3.456.

Black, J. Stewart, dan Allen J. Morrison. “The Character of Global Leaders.” Dalam Advances in Global Leadership, 8:183-204. Advances in Global Leadership 8. Emerald Group Publishing Limited, 2014. https://doi.org/10.1108/S1535-120320140000008016.

E Mulyasa. Manajemen Pendidikan Karakter. 5 ed. Jakarta: Bumi Aksara, 2016.

El-Bassiouny, Noha, Ahmed Taher, dan Ehab Abou-Aish. "An empirical assessment of the relationship between character/ethics education and consumer behavior at the tweens segment: the case of Egypt." Young Consumers 12, no. 2 (14 Juni 2011): 159-70. https://doi.org/10.1108/17473611111141614.

Fitriani, Mohamad Iwan. "Systemic and Systematic Steps of Leadership on Transforming Symbolic into Substantive Characteristic of Madrasah.” Jurnal Pendidikan Islam 3, no. 1 (22 Juni 2017): 1-16. https://doi.org/10.15575/jpi.v3i1.1203.

Gardner, Howard. "Memory and the Brain." New York Times. 24 Februari 2003, bag. Editorials/Letters. http://search.proquest.com/docview/92578371/citation/3A9051008EB845DDPQ/ 20. Multiple intelligences: the theory in practice. 30. dr. New York, NY: Basic Books, 2002. 
Muhammad Hifdil Islam, Mohammad Hilmy Baihaqy Yussof

Gardner, Howard, dan Thomas Hatch. "Educational implications of the theory of multiple intelligences." Educational researcher 18, no. 8 (1989): 4-10. http://edr.sagepub.com/content/18/8/4.short.

Graff, Chelsea. "The Effectiveness of Character Education Programs in Middle and High Schools." Counselor Education Master's Theses, 1 April 2012. https://digitalcommons.brockport.edu/edc_theses/127.

Guilford, J. P. "Creative abilities in the arts." Psychological Review 64, no. 2 (1957): 110-18. https://doi.org/10.1037/h0048280.

Hasanah, Aan, Neng Gustini, dan Dede Rohaniawati. "Cultivating Character Education Based on Sundanese Culture Local Wisdom.” Jurnal Pendidikan Islam 2, no. 2 (21 Juni 2016): 231-53. https://doi.org/10.15575/jpi.v2i2.788.

Islam, Muhammad Hifdil. "Model Pendekatan Halaqotul Mu`Allimin Al-Islamiyah Dalam Membentuk Kepribadian Yang Rahmatan Lil Alamin Sebagai Identitas Kebangsaan Di Pondok Pesantren Al-Mashduqiah." Proceedings of Annual Conference for Muslim Scholars 3, no. 1 (26 November 2019): 491-503. http://proceedings.kopertais4.or.id/index.php/ancoms/article/view/263.

. "Tolerance in Persepective of Qur'an and Bibel (Comparative Analysis of Religious Tolerance in Diverses Community)." Humanistika 3, no. 2 (1 Juni 2017): 45-58. https://www.ejournal.inzah.ac.id/index.php/humanistika/article/view/160.

Ismail, Ismail. "GURU KREATIF; Suatu Tinjauan Teoritis.” Jurnal Al-Qalam: Jumal Kajian Islam \& Pendidikan 11, no. 2 (28 Desember 2019): 15-30. https://doi.org/10.47435/al-qalam.v11i2.425.

Kirschenbaum, Howard. 100 ways to enhance values and morality in schools and youth settings. Boston: Allyn and Bacon, 1995.

Lickona, Thomas. Character matters: how to help our children develop good judgment, integrity, and other essential virtues. New York: Simon \& Schuster, 2004.

—. Educating for Character: How Our Schools Can Teach Respect and Responsibility. New York: Bantam Books, 2009.

Majid, Abd. Pendidikan berbasis ketubanan membangun manusia berkarakter. Bogor: Ghalia Indonesia, 2014.

Majid, Abdul, dan Dian Andayani. Pendidikan agama Islam berbasis kompetensi: konsep dan implementasi kurikulum 2004. Cet. 1. Bandung: Remaja Rosdakarya, 2004. 
Megawangi, Ratna. "Pengembangan program pendidikan karakter di sekolah: pengalaman sekolah karakter," 2010.

Nucci, Larry P., Tobias Krettenauer, dan Darcia Narváez, ed. Handbook of moral and character education. Second edition. Educational psychology handbook. New York: Routledge, 2014.

Oktari, Dian Popi, dan Warlim Warlim. "Internalization of Values Character Education in Learning English,” 416-21. Atlantis Press, 2019. https://doi.org/10.2991/conaplin18.2019.294.

Rachmawati, Yeni. Strategi Pengembangan Kreativitas Pada Anak. Prenada Media, 2012.

Siswanto. "The Islamic Moderation Values on the Islamic Education Curriculum in Indonesia:

A Content Analysis." Jurnal Pendidikan Islam 8, no. 1 (2019): 121-52. https://doi.org/10.14421/jpi.2019.81.121-152.

Stein, Morris I. "Creativity and Culture." The Journal of Psychology 36, no. 2 (1 Oktober 1953): 311-22. https://doi.org/10.1080/00223980.1953.9712897.

Sternberg, Robert J. Handbook of Creativity, 1999.

Supriadi, Dedi. Kreativitas, kebudayaan, dan perkembangan Iptek. Alfabeta, 1996.

Supriyadi, Dedy. Filsafat Islam. 3 ed. 3. Bandung: Pustaka Setia, 2013.

Zins, Joseph E., John W. Payton, Roger P. Weissberg, dan Mary Utne O’Brien. “Social and emotional learning for successful school performance." Dalam The science of emotional intelligence: Knowns and unknowns, 376-95. Series in affective science. New York, NY, US: Oxford University Press, 2007.

Zubaedi. Desain Pendidikan karakter, Konsepsi dan Aplikasinya dalam Pendidikan. Jakarta: Kencana Prenada, 2011. 